\title{
EXECUTIVE INFORMATION SYSTEM PENJUALAN BAHAN KIMIA
}

\author{
Khanna Tiara ${ }^{1,}$ \\ Nurman Fhirmanda ${ }^{2}$ \\ Muhammad Liwail Hamdi ${ }^{3}$ \\ ${ }^{123}$ Perguruan Tinggi Raharja \\ Email: khanna.tiara@,raharja.info ${ }^{l,}$ nurmanfhirmanda@raharja.info, \\ liwail.hamdi@raharja.info ${ }^{3}$
}

\begin{abstract}
Needs this information now become an absolute necessity for an organization or company to win a competition. Where the information is used to support decision-making, so it takes delivery of accurate information and fast in order to get no less than its competitors. Such information contains conditions that occur inside and outside the company that would later be used as a basis for strategic planning and work program. Along with the development of information needs, especially for the executive decision-making in order to determine the condition and performance of the company, then developed an information system called Exective Information System (EIS). With EIS information can be displayed in the form are concise and displays data according to the needs that facilitate an executive in control at all times. The sales process is currently running are still using manual systems are still using data logging process so it takes a long time for the production ofreports andreportthe resultingdata isnot necessarilyaccurate. Withthe problems above, it needs a system that can help the work of employees so that the report can be generated just in time and the resulting data is more accurate.
\end{abstract}

Keywords: EIS, chemicals, information

\begin{abstract}
ABSTRAK
Kebutuhan informasi sekarang ini menjadi kebutuhan mutlak bagi suatu organisasi atau perusahaan untuk memenangkan sebuah persaingan. Dimana informasi digunakan sebagai penunjang pembuat keputusan, sehingga dibutuhkan penyampaian informasi yang akurat dan cepat dalam mendapatkannya agar tidak kalah dari pesaingnya. Informasi tersebut berisi kondisi yang terjadi di dalam maupun di luar perusahaan yang selanjutnya akan digunakan sebagai dasar untuk perencanaan strategis dan program kerja. Seiring dengan berkembangnya kebutuhan informasi khususnya untuk para executive guna pengambilan keputusan dan untuk mengetahui kondisi kinerja perusahaan, maka berkembanglah sebuah sistem informasi yang disebut Executive Information System (EIS). Dengan EIS informasi dapat ditampilkan dalam bentuk secara ringkas dan menampilkan data sesuai dengan kebutuhan sehingga mempermudah seorang eksekutif dalam pengontrolan setiap saat. Proses penjualan yang berjalan saat ini masih menggunakan sistem yang manual yaitu masih menggunakan proses pencatatan data sehingga membutuhkan waktu yang lama untuk pembuatan laporan dan laporan yang dihasilkan datanya belum tentu akurat. Dengan permasalahan diatas maka dibutuhkan suatu sistem yang dapat membantu pekerjaan pegawai sehingga laporan yang dihasilkan bisa tepat pada waktunya dan data yang dihasilkan lebih akurat.
\end{abstract}

Kata kunci : EIS, bahan kimia, informasi 


\section{PENDAHULUAN}

Perkembangan informasi pada saat ini menjadi kebutuhan yang mutlak bagi suatu organisasi atau perusahaan untuk memenangkan sebuah persaingan. Dimana informasi digunakan sebagai penunjang pengambilan keputusan, sehingga dibutuhkan penyampaian informasi yang cepat, tepat dan akurat dalam mendapatkannya agar tidak kalah dari pesaingnya. Informasi tersebut berisi situasi dan kondisi yang menjadi di dalam maupun di luar perusahaan yang selanjutnya akan digunakan sebagai bahan evaluasi dasar untuk perencanaan strategis dan program kerja selanjutnya.

Seiring dengan berkembangnya informasi khususnya untuk para eksekutif guna pengambilan keputusan dan untuk mengetahui kondisi kinerja perusahaan, maka berkembanglah sebuah sistem informasi yang disebut Executive Information System (EIS). Dengan EIS informasi dapat ditampilkan dalam bentuk secara ringkas dan menampilkan data sesuai dengan kebutuhan sehingga mempermudah seorang eksekutif dalam pengontrolan setiap saat. Begitu juga dengan perusahaan yang menjual beberapa bahan kimia yang terdiri dari ESL dan HCL dimana pemilik perusahan tersebut kesulitan untuk menganalisa data penjualan secara keseluruhan karena laporan yang masih ada belum fleksibel dimana laporan tidak dibuat menjadi ringkas sehingga para manajer butuh waktu dalam mengolah data.

\section{LANDASAN TEORI}

\section{- Definisi Sistem Informasi}

Menurut Nugroho (2011:128), "Sistem informasi adalah sebuah sistem yang mempunyai fungsi mengumpulkan, memproses, menyimpan, menganalisis, dan menyebarkan informasi untuk tujuan yang spesifik".

Menurut Sutabri (2012:46), "Sistem informasi adalah suatu sistem di dalam suatu organisasi yang mempertemukan kebutuhan pengolahan transaksi harian yang mendukung fungsi operasi organisasi yang bersifat manajerial dengan kegiatan strategi dari suatu organisasi untuk dapat menyediakan kepada pihak luar tertentu dengan laporan-laporan yang diperlukan".

\section{Definisi Critical Succes Factors}

Menurut Rockart dan Bullen 1981 MIT dalam Witarto (2004:110), CSF merupakan sejumlah variable yang mempengaruhi aktivitas yang sekarang atau yang akan datang, dalam mencapai target pekerjaannya. Metoda CSF membantu pendefinisian variable. Dengan demikian, manajer akan meningkatkan pemahamannya tentang situasi diruang kendalinya.

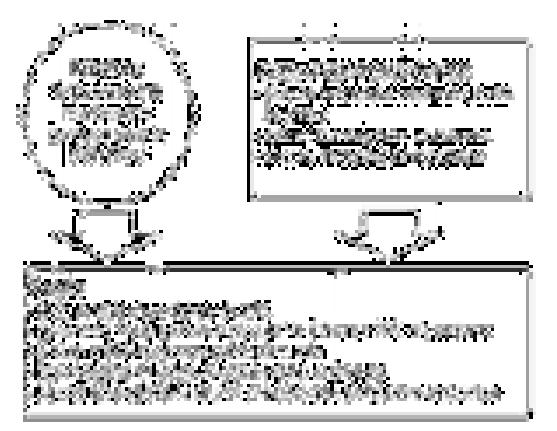

Gambar 1. Critical Succes Factors

CSFs dalam konteks perencanaan strategis sistem informasi digunakan untuk menafsirkan dengan jelas tujuan, taktik, dan kegiatan operasional dalam hal kebutuhan informasi kunci dan manajer dan kekuatan dan kelemahan dari sistem organisasi yang sudah ada.

Peranan CSFs dalam perencanaan strategis adalah sebagai penghubung antara strategi bisnis organisasi dengan strategi sistem informasi yang dimiliki, memfokuskan proses perencanaan strategis sistem informasi pada area yang strategis, memprioritaskan usulan aplikasi sistem informasi dan mengevaluasi strategi sistem informasi. 


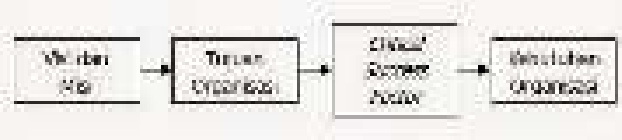

Gambar 2. Langkah-Langkah Elaborasi Tujuan Organisasi

\section{Definisi Executive Information System (EIS)}

Menurut Triandini dkk (2010:47), "Executive Information System (EIS) merupakan aplikasi sistem informasi yang terdapat dalam manajemen puncak. Dalam level manajemen puncak akan melihat hasil dari analisa dalam level MIS yang telah diringkas".

Menurut Indrajit (2012:1), "Executive Information System (EIS) merupakan salah satu feature yang banyak ditawarkan para pembuat perangkat lunak kepada perusahaan".

\section{PERMASALAHAN}

Prosedur sistem yang sedang berjalan saat ini pada konsumen atau pelanggan dapat melakukan pemesanan dengan 3 (tiga) cara, yaitu melalui telepon, faksimili maupun datang langsung dengan menyebutkan pesanan barang beserta banyaknya barang yang diinginkan lalu pesanan dicatat secara manual oleh bagian marketing. Setelah melakukan pemesanan, dilakukan konfirmasi secara tatap muka antara pelanggan dan bagian marketing. Kemudian membuat PO, SJ dan faktur pajak yang dilakukan oleh bagian marketing. Sekaligus menyerahkan surat tanda bukti pemesanan kepada pelanggan.

Konsumen atau pelanggan melakukan pembayaran melalui bagian administrasi secara langsung dengan menunjukkan surat tanda bukti pemesanan barang yang sebelumnya telah diberikan oleh bagian marketing. Manager membuat laporan penjualan (harian, bulanan dan tahunan), yang datanya diambil dari bagian marketing dan bagian administrasi. Laporan yang dibuat oleh manajer yaitu laporan pembelian barang, laporan penjualan barang, laporan kinerja karyawan. Setelah selesai manager memberikan laporannya kepadaDirektur Utama.

Rumusan masalah dalam penelitian ini adalah bagaimana proses menganalisa data penjualan dari data operasional untuk menghasilkan EIS yang berjalan saat ini, bagaimana membuat sistem yang dapat mengetahui kondisi intern yang terjadi dengan cepat dan akurat, dan bagaimana merancang Executive Information System (EIS). Berdasarkan rumusan masalah yang telah di identifikasi maka tujuan yang ingin dihasilkan adalah untuk memudahkan manajer dalam membuat laporan dan untuk memudahkan direktur untuk menganalisa data sehingga dapat dengan cepat dalam mengambil keputusan.

\section{LITERATURE REVIEW}

1. Penelitian ini dilakukan oleh Rosidiana (2011) berjudul "Perancangan Sistem Data Mining untuk Panel Pimpinan Berbasis Web pada Perguruan Tinggi Raharja". Salah satu aspek dalam dunia Pendidikan di dalam sebuah Perguruan Tinggi adalahpengambilan keputusan yang cepat, tepat, hemat dan akurat, yang terdukung dengan data yang dapat di percaya (real time) dan dapat diakses secara langsung. Panel pimpinan Perguruan Tinggi Raharja memuat semua data statistik pada tiap semester yang didasarkan pada IMM (Indeks Mutu Mahasiswa) dan IMD (Indeks Mutu Dosen) yang dapat diakses oleh akademik dan pimpinan. Sebagian besar, sistem terebut belum mampu menyediakan informasi yang representative dan relevan bagi tiap penggunanya untuk pengambilan keputusan dan menunjang kualitas pendidikan di Perguruan Tinggi Raharja. Untuk menyelesaikan permasalahan tersebut perlu dikembangkan sistem pendukung keputusan (SPK) dengan konsep data mining sebagai penunjang sistem untuk pelaksanaan evaluasi terhadap pencapaian tujuan. Pengembangan dan terobosan tersebut 
dimaksudkan untuk menciptakan tools bagi manajemen dalam melaksanakan fungsi manajerialnya, khususnya dalam melakukan evaluasi kinerja secara utuh. Hal ini karena sistem informasi yang ada pada Perguruan Tinggi Raharja sebagian besar dibangun menggunakan konsep database. Dengan demikian, informasi tersebut diharapkan dapat menghasilkan informasi sesuai kebutuhan manajemen (relevan) dan dapat digunakan untuk evaluasi kinerja organisasi pada Perguruan Tinggi Raharja.

2. Penelitian ini dilakukan oleh Kusuma (2012) berjudul "Aplikasi EIS (Executive Information System) Untuk Monitoring Transaksi Penjualan dan Pembelian". Penggunaan aplikasi EIS (Executive Information System) untuk monitoring transaksi penjualan dan pembelian berbasis teknologi desktop dapat memudahkan owner (pemilik) dalam kegiatan monitoring data transaksi penjualan dan pembelian, serta data stok barang, karena dengan pemanfaatan aplikasi ini pemilik dapat mengetahui informasi yang diinginkan dari jarak jauh sekalipun. selama server dan client terhubung pada koneksi internet. Sehingga memudahkan owner dalam memonitor hasil transaksi jual beli setiap waktunya serta monitoring stok barang tanpa harus datang langsung ke perusahaan yang dimaksud untuk mendapatkan informasi yang diinginkan.Jadi, pengimplementasian aplikasi ini sangat dibutuhkan untuk memperlancar dan memudahkan tugas pemilik dalam memonitoring kegiatan-kegiatan di perusahaan sehingga meminimalisir terjadinya hal-hal yang dapat merugikan perusahaan.

3. Penelitian ini dilakukan oleh Rendy Hendrawan (2011) berjudul "Sistem Informasi Eksekutif untuk Pengolahan Data Penjualan di UD.Waskita Karya”. Sistem Informasi Eksekutif (EIS = Executive Information System) merupakan salah satu ciri yang banyak ditawarkan para pembuat perangkat lunak kepada perusahaan. Modul yang diperuntukkan bagi para anggota Direksi dan Manager senior ini menawarkan kemudahan-kemudahan tertentu bagi para pelaku utama bisnis ini untuk melakukan kontrol secara langsung terhadap perusahaan yang dipimpinnya. seorang eksekutif tidak mungkin cukup dengan memasukkan input lewat menu yang ada harus membuat query terlebih dahulu untuk bisa mengakses dengan 1 atau lebih dari 2 dimensi akan lebih banyak waktu dan tenaga yang dikeluarkan untuk membuat query-nya. Seorang eksekutif yang berfungsi sebagai pengambil keputusan akan terbuang waktunya apabila tidak didukung sebuah sistem yang membantu mengatasi segala permasalahan data yang ingin diolahnya. Perusahan yang bergerak di bidang furniture UD. WASKITA KARYA dimana perusahaan tersebut mempunyai kendala atau masalah yang dialami oleh eksekutif dalam analisa data penjualan. Pihak eksekutif selama ini selalu mengalami kesulitan dalam menganalisis data penjualan karena di sistem manajemennya masih menggunakan laporan-laporan yang bersifat manual dan memakan waktu, tenaga, pikiran, apabila untuk menganalisa data penjualan yang sangat banyak sedangkan pihak manajemen tidak ada waktu untuk menganalis data sebanyak itu. UD.WASKITA KARYA sangatlah membutuhkan sistem informasi yang dapat mengcover semua data penjualan agar pihak eksekutif mampu melakukan tindakan yang penting untuk meningkatkan jumlah penjualan di tiap periodenya. Solusi yang mulai banyak dikembangkan saat ini untuk mengcover kebutuhan para eksekutif dalam hal manajemen data lintas dimensi yaitu melalui Sistem Informasi Eksekutif. Dalam aplikasi EIS ini dapat melakukan penanganan query dalam menampilkan data penjualan dengan berbagai lintas dimensi, dengan adanya fasilitas drill 
down dalam aplikasi EIS ini mempermudah eksekutif untuk melakukan penangan dimensi yang lebih mendetail. Rancangan sistem aplikasi EIS yang dibuat dapat mengimplementasikan ke aplikasi dan berjalan dengan baik.

4. Penelitian ini dilakukan oleh Utomo dkk (2013) berjudul "Perancangan Sistem Informasi Eksekitif Studi Kasus di UGM". Eksekutif memerlukan informasi kinerja organisasi untuk menentukan kebijakan yang diambil. Universitas Gadjah Mada (UGM) merupakan salah satu lembaga institusi pendidikan tinggi terbesar di indonesia dengan jumlah program studi terbanyak. Pengelolaan dan peningkatan kualitas berbagai program studi yang ada menjadi perhatian utama level eksekutif dalam rangka mewujudkan visi UGM sebagai perguruan tinggi nasional berkelas dunia. Sistem informasi yang ada di UGM merupakan sistem informasi yang heterogen. Ada beberapa program studi yang menggunakan aplikasi universitas, namun ada pula yang memiliki macam aplikasi untuk kegiatan operasional hariannya sendiri. Data operasional yang dibutuhkan untuk sumber informasi pengambilan keputusan menjadi tersebar ke seluruh unit kerja yang ada di UGM. Kondisi tersebut mengakibatkan perlunya usaha ekstra untuk mendapatkan informasi untuk pengambilan keputusan strategik. Berbagai pendekatan telah dilakukan untuk menangani permasalahan tersebarnya data di setiap unit kerja di UGM. Pendekatan yang saat ini sedang dilakukan adalah dengan mengintegrasikan informasi berdasarkan kepemilikan data primer. Data terkait sumber daya manusia, unit kerja yang memiliki sistem informasi tersendiri untuk mengolah data tersebut diarahkan untuk mengirimkan informasi terkait ke sistem Direktorat Sumber Daya Manusia. Jika data sudah terkumpul, semua unit yang membutuhkan data dapat mengakses secara langsung ke pemilik data primer tersebut. Mekanisme yang digunakan, baik untuk pengiriman informasi dari unit kerja ke pemilik data primer maupun sebaliknya, adalah menggunakan teknologi web service. Mekanisme integrasi informasi ke pemilik data primer menimbulkan kesempatan untuk pengembangan sistem informasi eksekutif. Sistem in formasi eksekutif yang mengambil data dari pemilik data primer diharapkan dapat meningkatkan validasi pengukuran kinerja. Sistem informasi eksekutif ini diharapkan dapat membantu proses pengambilan keputusan pada level eksekutif di UGM.

5. Penelitian ini dilakukan oleh Nina Rahayu (2013) berjudul "Perancangan Executive Information System (Eis) Dalam Bidang Penjualan Pada Karinda Cafe Dan Resto". Dengan EIS informasi dapat ditampilkan dalam bentuk secara ringkas dan menampilkan data sesuai dengan kebutuhan sehingga mempermudah seorang eksekutif dalam pengontrolan setiap saat. Begitu juga yang dirasakan Karinda Cafe dan Resto dimana Cafe dan Resto yang terletak di Tangerang tepatnya di Perumahan Metro Permata ini menyediakan beragam menu yang terdiri dari menu asia dan nusantara, dimana owner Cafe dan Resto sendiri sulit untuk menganalisa data penjualan secara keseluruhan karena data yang ada masih berbentuk data detil (data transaksi penjualan) belum adanya ringkasan data (summerize data). Metodelogi yang digunakan yaitu analisa dengan menggunakan metode SWOT (Strengths, Weaknesses, Opportunity, Threaths) sehingga dapat diketahui kondisi Karinda Cafe dan Resto secara keseluruhan baik dari dalam maupun dari luar dan perancangan yang terstrukur mulai dari sistem yang diusulkan melalui UML (Unified Modeling Language) dan pengujian program yang diusulkan menggunakan black box 
testing. Ada pun perancangan programnya menggunakan bahasa pemrograman PHP dan library fussion chart untuk menampilkan data dalam betuk diagram. Dengan adanya sistem yang baru ini diharapkan manajer atau owner karinda cafe dapat mudah dalam menganalisa data dari hasil transaksi atau data operasional.

\section{PEMECAHAN MASALAH}

Untuk mengatasi berbagai masalah diatas, maka diperlukan proses yang cepat dan efisien dalam mengakses seluruh data yang banyak dan tidak teratur pada media penyimpanan yang berupa sebuah sistem, terlebih untuk suatu sistem informasi yang akurat. Dalam mencapai tujuan memudahkan manajer dalam membuat laporan dan untuk memudahkan direktur untuk menganalisa data sehingga dapat dengan cepat dalam mengambil keputusan, maka diperlukan metode analaisa yang nyata.

Pada pemecahanan masalah menggunakan metode analisa CSF ini akan dielaborasikan visi dan misi menjadi tujuan bisnis bagi perusahaan yang kemudian akan diaplikasikan menggunakan CSF analisis untuk menemukan kebutuhan perusahaan. Langkah-langkah elaborasi tersebut dapat dijelaskan pada gambar di bawah ini, yaitu

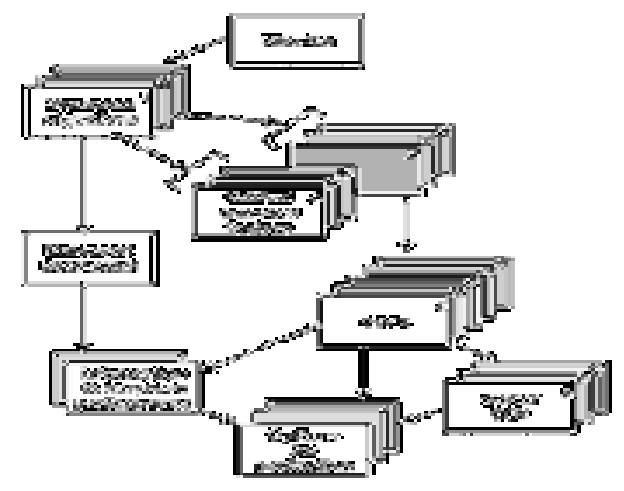

Gambar 3. Critical Succes Factors
Berdasarkan hasil observasi pada perusahaan, didapatkan pernyataan visi misi dari perusahaan. Tujuan utama dari perusahaan tertuang dalam sistem pengolahan informasi barang, pengembangan penelitian dan kegiatan, memaksimalkan penerapan program penelitian, dan keakuratan data yang dapat dimonitoring sehingga menghasilkan suatu laporan yang dapat memudahkan pimpinan dalam mengambil suatu keputusan.

Use Case program dalam pemecahan masalah merupakan keterangan yang lebih rinci tentang bagaimana setiap langkah program atau prosedur sesungguhnya akan dilaksanakan. Use Case ini menunjukan setiap langkah program atau prosedur dalam urutan yang tepat saat terjadi. Berikut Use Case Sistem Penjualan Bahan Kimia, yaitu sebagai berikut :

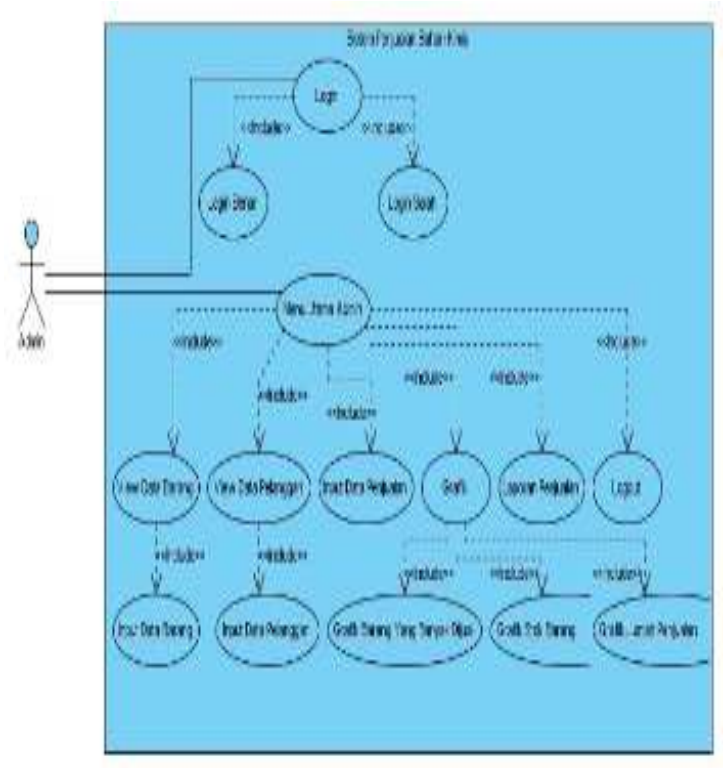

\section{Gambar 4. Use Case Penjualan Bahan Kimia}

Dapat dijelaskan gambar 4 Use Case Penjualan Bahan Kimia diatas pada saat ini terdiri dari 1 system yang mencakup seluruh kegiatan yang sedang berjalan, 1 actor yang melakukan kegiatan, yaitu: Admin, 2 use case yang biasa dilakukan oleh actor-actor, dan 13 include yang meliputi verifikasi login benar, verifikasi login salah, input data barang, input data karyawan, cetak nota, laporan penjualan. 


\section{IMPLEMENTASI}

Tampilan sistem penjualan bahan kimia memiliki berbagai macam fitur yang dapat digunakan oleh admin dan manager yang terdiri dari:

\section{A. Tampilan Menu Data Barang}

Pada tampilan create barang yang dapat memberikan informasi data barang, yaitu kode barang, nama barang, satuan, harga, dan stok barang yang terdapat pada perusahaan mengenai persediaan barang didalamnya.

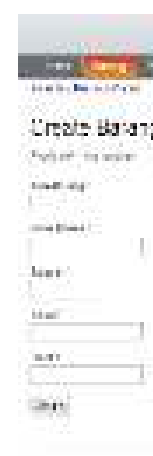

\section{Gambar 5. Tampilan Menu Data Barang}

B. Tampilan Menu Data Pelanggan

Tampilan ini menunjukan data pelanggan yang dilibatkan pada perusahaan dalam proses penjualan sehingga jika ada pelanggan yang ingin melakukan pembelian maka data sudah terhimpun dengan rapih.

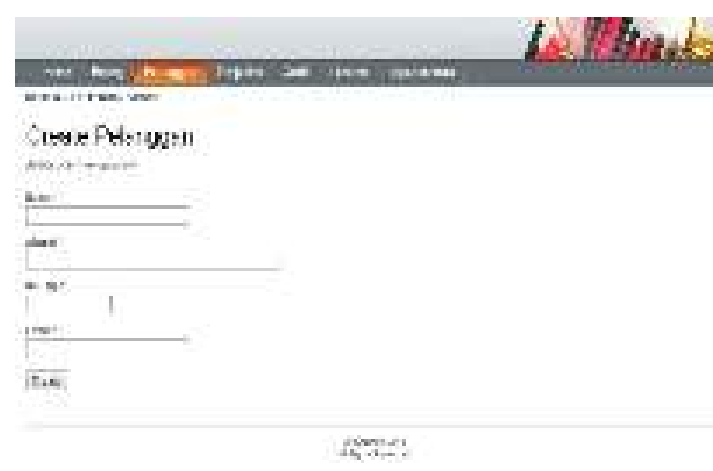

Gambar 6. Tampilan Menu Data Pelanggan
Tampilan Menu Penjualan

Pada tampilan ini tidak hanya data barang yang terhimpun dengan rapih tetapi data penjualan juga dapat dilihar, sehingga dapat dipastikan informasi yang didapatkan merupakan data penjualan yang jelas sehingga memudahkan pimpinan dalam mengambil suatu keputusan dengan laporan yang ada didukung dengan data yang lengkap.

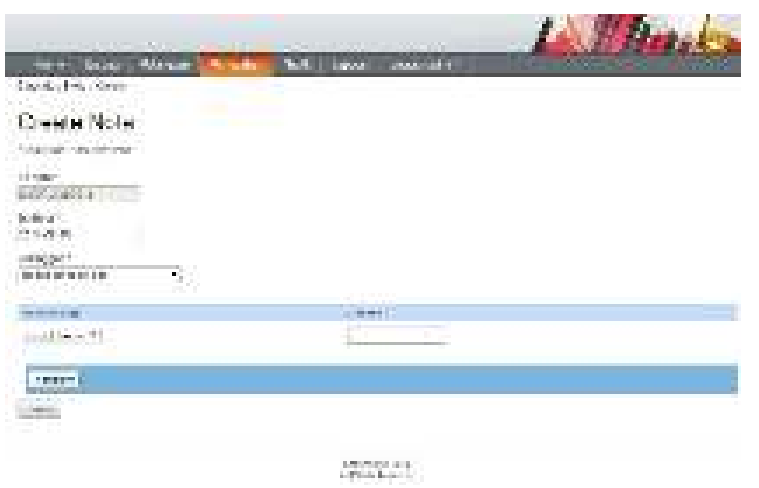

\section{Gambar 7. Tampilan Menu Penjualan}

Implementasi program Sistem Penjualan pada perusahaan dilakukan dengan menggunakan metode Black Box Testing. Metode Black Box Testing merupakan pengujian program yang mengutamakan pengujian tergadap kebutuhan fungsi dari suatu program. Tujuan dari metode Black Box Testing ini adalah untuk menemukan kesalahan fungsi pada program.

Pengujian dengan metode Black Box Testing dilakukan dengan cara memberikan sejumlah input pada program. Input tersebut kemudian diproses sesuai dengan kebutuhan fungsionalnya untuk melihat apakah program aplikasi dapat menghasilkan output yang sesuai dengan yang diinginkan dan sesuai pula dengan fungsi dasar dari program tersebut. Apabila dari input yang diberikan, proses dapat menghasilkan output yang sesuai dengan kebutuhan fungsionalnya, maka program yang dibuat sudah benar, tetapi apabila output yang dihasilkan tidak sesuai dengan kebutuhan fungsionalnya, maka masih terdapat kesalahan pada program tersebut, dan selanjutnya dilakukan 
penelusuran perbaikan untuk memperbaiki kesalahan yang terjadi.

Berikut ini adalah tabel pengujian Black Box berdasarkan sistem Penjualan untuk fungsi menu data barang, yaitu sebagai berikut:

\section{Tabel 1. Blackbox pada menu barang}

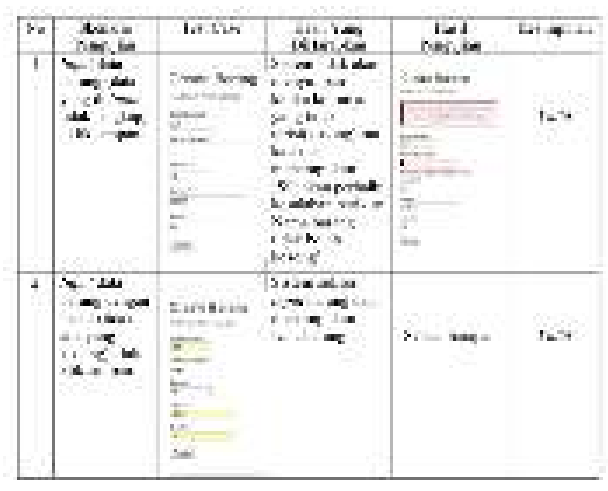

Berikut ini adalah tabel pengujian Black Box berdasarkan sistem Penjualan untuk fungsi menu data pelanggan, yaitu sebagai berikut:

Tabel 2. Blackbox pada menu pelanggan

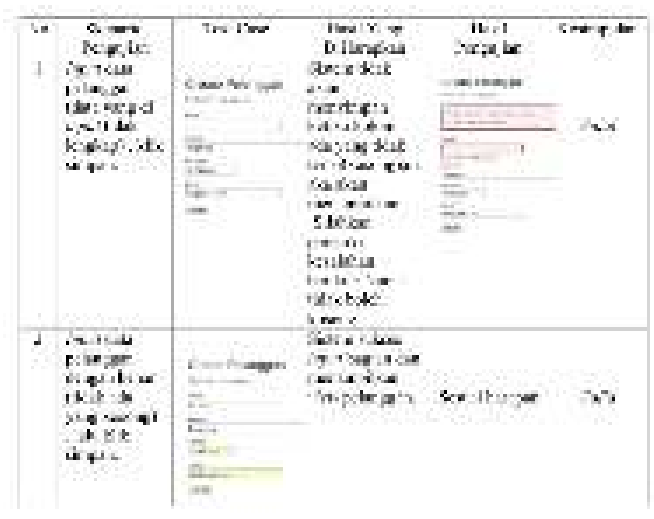

Berikut ini adalah tabel pengujian Black Box berdasarkan sistem Penjualan untuk fungsi menu penjualan, yaitu sebagai berikut:

Tabel 3. Blackbox pada menu penjualan

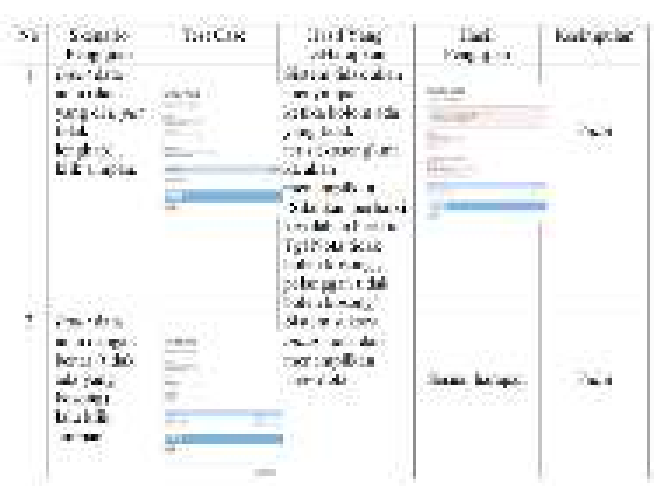

Setelah dilakukan pengujian dengan metode Black box yang dilakukan dengan cara memberikan sejumlah input pada program seperti contoh pengujian pada masing-masing mеnu dan sub тепи. Jika input data tidak lengkap maka sistem akan menampilkan pesan dan menyampaikan pesan yang sangat membantu admin jika admin mendapati kesalahan saat input data pegawai yang tidak lengkap, selanjutnya yang kemudian akan di proses sesuai dengan kebutuhan fungsionalnya dan dapat menghasilkan output yang sesuai dengan yang diinginkan oleh perusahaan.

\section{KESIMPULAN}

Dengan demikian dapat disimpulkan, bahwa dengan adanya sistem penjualan bahan kimia, dalam menganalisa informasi dari hasil data operasional manajer harus mengambil data dari admin untuk diolah kembali kedalam bentuk excel sehingga dari segi waktu ini kurang efisien. Untuk membuat sistem yang dapat mengetahui kondisi intern pada perusahaan dibutuhkan aplikasi Executive Information System (EIS) khusus pada bidang penjualan dimana informasi dapat mengetahui barang apa paling diminat dan yang tidak diminati oleh pelanggan.

Untuk merancang Executive Information System (EIS) dibuat sebuah sistem yang meringkas data operasioal yaitu mengunakan bahasa pemrograman PHP disamping untuk memanggil query ke database aplikasi juga dapat diakses dimana saja asal komputer terkoneksi dengan internet. Dan agar informasi disajikan dengan menarik maka dibuat kedalam diagram yaitu dengan menggunakan library high chart. 
Dengan adanya sistem penjualan bahan kimia ini, diharapkan pengelolaan data barang yang ada menjadi lebih mudah karena penggunaan database yang tergintegerasi dengan baik dan diproses secara terkomputerisasiyang dapat memungkinkan hasil pengolahan data akan lebih cepat, tepat, akurat sehingga persediaan barang didalam perusahaan dapat termonitoring dengan baik.

\section{DAFTAR PUSTAKA}

1. Mustakini. Jogiyanto Hartono. 2009. SistemTeknologi Informasi. Yogyakarta: Andi.

2. Nugroho, Bondan Dwi, dan Imam Azhari. Sistem Informasi Inventori FADEGORETAS!! TM Berbasis Barcode. Yogyakarta: Universitas Ahmad Dahlan. Vol. 1, No. 2, September 2011.

3. Witarto, Rockart dan Bullen. 1981. Memahami Sistem Informasi. Bandung: Informatika.

4. Sutabri. Tata. 2012. Konsep Sistem Informasi. Yogyakarta: Andi.

5. Triandini. Evi dan Suardika. I Gede. 2012. Step by Step Desain Proyek Menggunakan UML. Yogyakarta: Andi.

6. Rahayu, Nina. 2013. "Perancangan Executive Information System (Eis) Dalam Bidang Penjualan Pada Karinda Cafe Dan Resto".

7. Rosidiana. 2011. "Perancangan Sistem Data Mining untuk Panel Pimpinan Berbasis Web pada Perguruan Tinggi Raharja".

8. Kusuma. 2012. "Aplikasi EIS (Executive Information System) Untuk Monitoring Transaksi Penjualan dan Pembelian".

9. Rendy, Hendrawan. 2011. "Sistem Informasi Eksekutif untuk Pengolahan Data Penjualan di UD.Waskita Karya".

10. Utomo. 2013. "Perancangan Sistem Informasi Eksekitif Studi Kasus di UGM".
11. Indrajit, RichardusEko. 2012. Seluk Beluk Sistem Informasi Eksekutif. 